\title{
Market Foundation for Sustainable Economy Growth and Energy Policy (Georgian Case)
}

\author{
David Aslanishvili \\ Department of Finance and Banking, Faculty of Economy and Business, Tbilisi State University, Tbilisi, Georgia \\ Email: d.aslanishvili@gmail.com
}

Received 23 February 2016; accepted 20 March 2016; published 23 March 2016

Copyright ( 2016 by author and Scientific Research Publishing Inc.

This work is licensed under the Creative Commons Attribution International License (CC BY).

http://creativecommons.org/licenses/by/4.0/

(c) (i) Open Access

\begin{abstract}
In this article we have overviewed the present conditions of Georgia and proposed some ideas about how to turn Georgia from a backward country into a developed one. The article, "Market foundation for sustainable economy growth and energy policy (Georgian Case)", highlights the importance of the strong and reliable energy system for sustainable economic growth, their interaction, the luck of market tools and market price (capitalization) and energy problems in Georgia, including the dysfunctions of regulatory Commission. At the same time, we have highlighted and presented the negative gap between the per capita GDP and energy consumption rates in Georgia and the developed countries, like Switzerland, the US and the Europe. Also, it had investigated the ways how to encourage economic growth in energy sector in Georgia based on modern market tools.
\end{abstract}

\section{Keywords}

Economy Growth, GDP, Energy Policy, Stock Market, Regulatory Commission

\section{Introduction}

The mission of research proposal is to find out the real solution to rapidly developed countries like Georgia based on modern capital market tools.

Economic progress and improving living standards of the population depends largely on the provision of high economic growth. That issue itself heavily depends on energy sources.

To illustrate wide gap between the developed economy and the weak one, let us compare the current level of per capita GDP of Switzerland to Georgian one: an average income of middle-income Swiss citizen (58,996.90 USD) [1] is more than 2 years' (24 months) income of Georgian citizen (2254.38 USD) [2].

If we look closely on per capita GDP in Georgia [3], its figures do not show the rapid growth tendency to narrow negative gap in development: (Figure 1). 


\begin{tabular}{|c|c|c|c|c|c|c|c|}
\hline & 2010 & 2011 & 2012 & 2013 & 2014 & I15* & II 15* \\
\hline $\begin{array}{l}\text { GDP real } \\
\text { growth, } \\
\text { percent }\end{array}$ & 6.2 & 7.2 & 6.4 & 3.4 & 4.6 & 3.3 & 2.5 \\
\hline $\begin{array}{l}\text { GDP } \\
\text { deflator, } \\
\text { percent }\end{array}$ & 8.5 & 9.5 & 1.1 & -0.8 & 3.8 & 6 & 5.8 \\
\hline
\end{tabular}

Figure 1. Gross domestic product (GDP).

The only proven way to change situation drastically is the stable economic growth and attraction of investment. In our research, we think Georgian energy objects and its investment potential are the key to drive Georgia out of poverty and stimulate the rapid economic growth.

\section{Analysis of the Market Foundation of Sustainable Economic Growth}

Development, economic growth and raising the standard of living in the country are all linked directly to capital market development.

Georgian energy potential can be described based on facts: 26,000 rivers, length of it $60,000 \mathrm{~km}$ is the key issue for Georgia. Potential water resources cover 96.5 cubic meters. Based on modern technology just 300 rivers can be reviewed as the technologically attractive for energy supply jobs. Its potential energy output is equal to $15,000 \mathrm{MV}$, with average annual energy production up to 50 billion Kilowatt/hours equivalent [4].

In the modern world it is impossible to develop the economy and increase supply of affordable energy sources without attractive tariffs (investment climate) to stimulate investment. At the same time the key issue is the effectiveness of production. We can say that there is a direct relationship between economic growth and energy demand. Number of researchers claims the fundamental role of energy in economic growth issue. It should be noted that as the result of the leading European countries energy efficiency policy, we have energy consumption growth. In fact, the growth of the welfare society is a direct link to the energy consumption [5].

To attract capital into energy objects, it is obligatory to have reliable and strong market foundation and its tools. Based on that, we have studied Georgian capital market and its main drivers-brokerage firms (investment banks) development level and readiness to invest.

One of the real levers, and the most acceptable and practical forms of investment are to invest in equities through the stock market. It is clear for the developed world how important the organized stock market is. This includes Western Europe, USA, Canada, Japan, China and other countries with powerful stock industries such as the New York Stock Exchange; Euronext; NASDAQ OMX; the London Stock Exchange and many others. The mediation business or brokerage/investment firms include Merrill Lynch; Morgan Stanley; Goldman Sachs; J.P. Morgan; Barclays Capital and many other investment banks.

The Georgian Stock Exchange (GSE) was established with the financial support of USAID and Barents Group in 2000. Immediately after its establishment, the Law of Georgia on Securities Market was developed and in 2004-2008 there were 42 brokerage firms in the country. These, under Georgian legislation, are institutions equal to investment banks. However, due to tightened regulations that came into effect after 2008, their number actually dropped dramatically and currently there are only five members of the GSE left, of which just one remained as independent and four are subsidiaries of commercial banks. There is a lot of objective or subjective reasons happened to delayed Georgia stock market development and to attract investment into energy sector of Georgia [6].

Normally the activity of a brokerage firm is directly connected with public trading at a stock exchange, and carried out in an open and transparent environment. This process is related only to market price. In 2000-2007 Georgia faced the problem of "closed bidding". Lately, the rules of bidding were changed at the stock exchange and the so-called "N parameter" was abolished. However, shortly thereafter the ruling political and economic teams implemented decisive measures against free price formation in Georgia. Research has ascertained that Georgia failed to achieve results anywhere near those of developed countries, with miserable results caused by problems between the two basic means of attracting monetary resources - bank loans and the stock market.

In financially successful and developed countries, these two mechanisms: bank loans and the stock market are designed to attract money and create a mutually beneficial synergy. In Georgia, there is only one mechanism to attract money resources - the bank loan. In general the Georgian commercial banking system tries its utmost to prevent the use of the second mechanism, the stock market, since it is considered a main competitor. 
The analysis of the structure of owners of Georgian Stock Exchange (source: securities registrar JSC Kavkasreestri, www.kavkasreestri.ge) shows that as of December 2015, 58\% of shares of the stock exchange were owned by its competitor-Georgian commercial banks. It means that Georgian commercial banks will not allow the development of their competitor-the stock market as it threatens their own preferential and successful financial position. According to this analysis, the situation is further complicated by the fact that under the legislation amended in 2008, both spheres of the monetary market have one mega regulator-the National Bank of Georgia [6].

It should be noted, that an essential attribute of the stock market - the National Securities Commission of Georgia was abolished by so-called "liberal legislative amendments" made in 2007-2008. The powers of the NSC were transferred to the regulator of Georgian commercial banks and lobbyist of their interests, the National Bank of Georgia. Simultaneously, very tough policies were enacted against brokerage firms, and as a result, as of 2015, there are practically no non-banking brokerage firms in Georgia.

According to the study, the statistical results of Georgia's stock industry are as follows: in 2000-2002, the shares of 282 Georgian joint stock companies were admitted to trading on the Georgian Stock Exchange, while 147 joint stock companies were potentially discussing the admission of shares to the stock exchange. This amount actually remained unchanged by 2007.

In 2003 there were 278 joint stock companies admitted to trading at GSE; in 2004, to 276; in 2005, their number was reduced to 253 and in 2006 to 242 . A small number of companies were included in so-called "Listing A" and "Listing B" tiers. The JSC Bank of Georgia was trading on two exchanges - the Georgian Stock Exchange and London Stock Exchange. Since 2008, when the restrictive legislative amendments were approved, there has been no "civilized" possibility for equity trading in Georgia, meaning that if there is a willingness to trade, securities admitted to the stock exchange can be transferred by simple inscription on paper, without any auction or trading - it is enough simply to sign the document. What is most important, this method has made the process of monitoring cash transactions absolutely opaque.

As the analysis shows, in parallel with the changes taking place in 2007-2008, the management of joint stock companies gradually lost any interest in equity trading in an open and transparent environment, once the law didn't require it. Thus, in 2006 there were 242 companies in the stock exchange's trading system (without listing), in 2007 their number was reduced to 161 and in 2013 reduced to 129. During the same period, the stock exchange turnover radically decreased in Georgia. In 2006-2007 the turnover of the trading system, including transactions concluded in an open and transparent environment - despite the $\mathrm{N}$ parameter obstacle amounted to GEL 167 - 169 million. In 2008 it decreased 14-fold (i.e. a 1400\% decrease) and continued to decrease in the following years. In 2013, the country's stock exchange turnover amounted to GEL 530,491 or 338-fold less compared to 2007 [6].

The problem of the Georgian stock market has been further aggravated by the global economic crisis. We have stated that during global crises a civilized state tries to support businesses, which did not happen in Georgia. Following the worsening economic, legislative and market situation, the regulator (National Bank of Georgia) increased the authorized capital requirements for brokerage firms, which had already been left without any function or their main sources of income. To make matters worse the NBG abolished three types of licenses and only recognized a General License for which requirements in practice could be met only by commercial banks and their subsidiaries. Today, a brokerage firm is required to have a capital of GEL 500,000 (or 250,000 USD) to maintain its license. According to this complicated scheme of capital recognition, only money resources are considered as a source of capital replenishment, which is against the background of market failure and does not enable an independent brokerage firm to compete with subsidiaries of commercial banks. Thus, the actual disappearance of the securities market industry as an alternative to a bank loan is now a fact. This is used by the National Bank of Georgia to promote the obedience of the securities market to the commercial banking sector (i.e. competitive structure).

As for the number of transactions made outside the stock exchange and any transparent environment, "fixing" amounted to 3453 trades in Georgia in 2008-2014. Their total amount in shares was 5,054,520,669 units, and the total value was GEL 1,233,305,848. This means that the "grey" market exceeded the amount of the open market 24-fold in 2008, 32-fold in 2009, 19-fold in 2010, 8-fold in 2011, 90-fold in 2012 and 100-fold in 2013. It means that the country's stock market was replaced by a grey, non-transparent, "wild-liberal" market.

Presently, Georgia's stock exchange has lost its key function as a foundation for price formation in the stock market. Therefore, any trading it shares or other securities has become senseless. We suggest legislative amend- 
ments as a solution in order to save and develop Georgia's stock exchange. A package of amendments to resolve the situation has been submitted to the Parliamentary Committee on Finance and Budget in October 2012, however due to lobby activity of Commercial banks it is not as agenda of the Georgian Parliament yet [6].

\section{Analysis of the Market Foundation of Energy Policy}

To illustrate the current situation, Georgian Annual output is 10 billion Kilowatt/hours equivalent and consumption is 9.7 Kilowatt/hours equivalent. In that field, any further economic growth can't be supply without additional energy sources [7] (Table 1).

In this regard, policy of local government and its Ministry of Energy is clear. At this stage, production is actually equal to the current consumption and the economic growth of the country will inevitably face an acute problem of energy for industrial and public requirements. It should be noted that Georgia has a very low per capita consumption of electricity. If we compare the energy consumption of the leading developed countries result is alarming for Georgia: Georgia's energy consumption per capita is 10 times less than the same figure for the United States and $4-5$ times less than the EU average [4].

In this condition, Georgia's rapid economic growth and improving living standards should be focused on two major points:

1) To support the energy sector in a competitive market activities;

2) To attract investments via road shows and legislative preferences.

It is important to decrease the disproportion in electricity generation and consumption in Georgia. At the present stage Georgia faces the power shortages in Winter and Autumn period of time and excess of electricity generation during the Spring and Summer time.

This time-term (season) energy shortfall can not be carried out because of lack of own capacity and it is usual practice to cover deficit using import of energy, but given the changing energy prices it is a threat to the country's macroeconomic and energy stability.

\subsection{Recent Development of Energy Market (2013-2015)}

In the last three years, foreign direct investment in the energy sector totaled 521.658 million dollars. 12 hydroelectric stations were constructed and added to the energy system of Georgia in 2013-2015. The total capacity of the new one's is equal to $170.7 \mathrm{MW}$, while the total investment in construction reached 283 million. USD. Different foreign companies invested into Georgia's energy sector such as: Tata Group, Clean Energy, K-Water, Translelectrika, Anadolu, Calik, Hydrolea. Some companies carry out large-scale projects, such us Khudoni HPP including 702 MW, Nenskra HPP-80 MW and Oni HPP-177 MW. During this period, according to official statistics, Georgia's foreign direct investment in the energy sector occupies the second place from the overall investment structure [8].

Table 1. Electro energy balance of Georgia (in mln Kilowatt) (2003-2013).

\begin{tabular}{ccccc}
\hline Year & Production & Consumption & Import & Export \\
\hline 2003 & 7132 & 6649 & 1080 & 236 \\
2004 & 6902 & 7388 & 1278 & 71 \\
2005 & 7061 & 7842 & 1399 & 122 \\
2006 & 7622 & 7879 & 777 & 96 \\
2007 & 8346 & 7815 & 433 & 626 \\
2008 & 8451 & 8075 & 649 & 680 \\
2009 & 8408 & 7642 & 255 & 749 \\
2010 & 10,058 & 8441 & 222 & 1524 \\
2011 & 10,105 & 9257 & 471 & 931 \\
2012 & 9698 & 9379 & 615 & 528 \\
2013 & 10,059 & 9690 & 484 & 450 \\
\hline
\end{tabular}




\subsection{The Place and Activity of Georgian National Energy and Water Supply Regulatory Commission (GNERC) in the Field of Investment Attractiveness and Economic Growth in Georgia}

Due to highly monopolized energy market in Georgia the problems of:

- Elimination of energy deficit;

- Rapid economic growth;

- Rising living standards.

Are directly attributed to the activity of GNERC [9] and to the special role of the Commission (GNERC)-legally independent unit, which can (together with the Ministry of Energy) within its powers:

1) To support the energy sector in a competitive market activities;

2) Openly and transparently presents the tariff structure and its components both for manufacturing (commercial one), and for public one (generation, transmission, dispatch, handling and distribution). Based on importance of energy price in production this issue directly links to the economic growth and prosperity;

3) To increase the investment attractiveness of different energy projects via internationally adopted practice (private-public one) Road Show to target public and private investment companies worldwide;

4) To determine and hold the number of existing standards or legislative requirements that hinder investments in energy production in a number of directions, etc.

Unfortunately, due to our analysis, the current structure and activity of GNERC does not show the will and tendency to fulfill its mission. Most of members are lawyers, there is luck of any person with finance and economic background and its activity is mostly depend on political will the ruling groups (and lobby members), rather than market and economic tendency. Of course, only a regulatory unit will not create an investment climate and it is important the readiness of local financial market and government policy to promote private companies. In that field, the clear example of such work is co-funding of large-scale projects (Nenskra and Khudoni HPP) from the state Partnership Fund [10].

\section{Conclusions}

Finally, once again we stress the need for a direct link between economic growth and business-friendly source of energy access, which is prerequisite for production facilities to be competitive and attractive investment point of production.

In addition, we would like to notice the necessity to diversify the energy sources to ease the economic backwardness and reduction of economic growth. It is vital to have the fair energy tariffs to create the competitive production in economy. In that field the Regulatory Commission (GNERC) has the legal power and functions to improve the quality of the sector's investment attractiveness.

\section{Acknowledgements}

The author wishes to thank all those whose support had a contribution in the production of this paper. Included in the list of valuable support are members of Georgian Business Palace, colleagues from University, Partners from Brokerage industry and Local Authorities.

\section{References}

[1] http://www.tradingeconomics.com/switzerland/gdp-per-capita

[2] http://www.tradingeconomics.com/georgia/gdp-per-capita

[3] http://geostat.ge/index.php?action=page\&p id=119\&lang=eng

[4] Mircxulava, D. (2014) Hydropower Energy Priority Development Program Facilitation. Presentation, Former Minister of Energy of Georgia, Georgian Business Palace.

[5] Madlener, R. and Alcott, B. (2009) Energy Rebound and Economic Growth: A Review the Main Issues and Research Needs. Energy, 34, 370-376. http://dx.doi.org/10.1016/j.energy.2008.10.011

[6] Aslanishvili, D. (2014) The Stock Market in Georgia: The Current Reality and an Uncertain Future. Scientific Popular Journal, Tsu Science, 6, 39-41.

https:/www.tsu.ge/data/file_db/PR/tsu\%20science\%202014\%20eng\%20web.pdf 
[7] Ministry of Energy of Georgia. Annual Reports 2013 and 2014. www.energy.gov.ge

[8] Kaladze, K. (2015) Vice Prime Minister. Minister of Energy “Energy Sector Investment Account”, 18 December 2015. www.energy.gov.ge

[9] (2016) Georgian National Energy and Water Supply Regulatory Commission (GNERC). www.gnerc.org

[10] http://fund.ge/eng/investment opportunities/37 